\title{
Investigation into the role of endogenous abscisic acid during ripening of imported
} avocado cv. Hass.

Journal of the Science of Food and Agriculture, Vol. 97, Issue 11, 30 August 2017, pp. 3656-3664 DOI:10.1002/jsfa.8225

\section{Marjolaine D Meyer, Gemma A Chope and Leon A Terry*}

\author{
Plant Science Laboratory, Cranfield University, Bedfordshire MK43 0AL, UK \\ * Correspondence to: Leon A Terry, Plant Science Laboratory, Cranfield University, \\ Bedfordshire MK43 0AL, UK. E-mail: l.a.terry@cranfield.ac.uk.
}

\begin{abstract}
BACKGROUND: The importance of ethylene in avocado ripening has been extensively studied. In contrast, little is known about the possible role of abscisic acid (ABA). The present work studied the effect of 1-MCP $\left(0.3 \mu \mathrm{L} \mathrm{L}^{-1}\right)$, e+ ${ }^{\circledR}$ Ethylene Remover and the combination thereof on the quality of imported avocado cv. Hass fruit stored for 7 days at $12^{\circ} \mathrm{C}$. Ethylene production, respiration, firmness, colour, heptose (C7) sugars and ABA concentrations in mesocarp tissue were measured throughout storage.
\end{abstract}

RESULTS: Treatment with $\mathrm{e}^{\circledR}$ Ethylene Remover reduced ethylene production, respiration rate and physiological ripening compared with controls. Fruit treated with 1$\mathrm{MCP}+\mathrm{e}+{ }^{\circledR}$ Ethylene Remover and, to a lesser extent 1-MCP alone, had the lowest ethylene production and respiration rate and hence the best preserved quality. Major sugars measured in mesocarp tissue were mannoheptulose and perseitol, and their

This article has been accepted for publication and undergone full peer review but has not been through the copyediting, typesetting, pagination and proofreading process, which may lead to differences between this version and the Version of Record. Please cite this article as doi: $10.1002 /$ jsfa.8225 
content was not correlated with ripening parameters. Mesocarp ABA concentration, as determined by mass spectrometry, increased as fruit ripened and was negatively correlated with fruit firmness.

CONCLUSIONS: Results suggest a relationship between ABA and ethylene metabolism since blocking ethylene, and to a larger extent blocking and removing ethylene, resulted in lower ABA concentrations. Whether ABA influences avocado fruit ripening needs to be determined in future research.

Keywords: $\mathrm{e}+{ }^{\circledR}$ Ethylene Remover; 1-MCP; imported avocado; C7 sugars; abscisic acid

\section{INTRODUCTION}

The importance of ethylene in ripening of avocado (Persea americana Mill.) has been extensively studied and it is widely accepted that the increase in the rate of autocatalytic ethylene production occurs before most of the compositional changes related to ripening. ${ }^{1-3}$ Considerably less is known about the function of the phytohormone abscisic acid (ABA) in avocado ripening. It has been suggested that ABA may be related to the ripening process ${ }^{4}$ and, in avocado, the concentration of the hormone accumulates in mesocarp tissue during maturity and ripening alongside ethylene biosynthesis, with a peak occurring just after that for ethylene production. ${ }^{4-6}$ Richings et al. found that phenotypically small cv. Hass avocado had a higher respiration rate and higher $\mathrm{ABA}$ content than fruit of larger size. ${ }^{7}$ Furthermore, a single application of exogenous ABA (48 $\mu \mathrm{g}$ per fruit) by infiltration to pre-climacteric cv. Hass avocado has been shown to advance climacteric ethylene biosynthesis and 
respiration peak, causing more rapid ripening. ${ }^{8}$ Application of exogenous ABA also accelerated induction of ethylene biosynthesis and advanced the onset of ripening in peaches $^{9}$, apple ${ }^{10}$, and mango ${ }^{11}$, possibly by enhancing tissue sensitivity to ethylene or stimulate 1-aminocyclopropane-1-carboxylic acid (ACC) synthase (ACS) accumulation and activity. ${ }^{9,10}$ As yet, limited research has been directed in recent years to determine the relationship between endogenous $\mathrm{ABA}$ and ripening in avocado.

Avocado fruit do not ripen whilst still attached to the tree but only do so after harvest. The nature of the factor(s) of ripening inhibition is not yet known, and researchers hypothesised that the seven-carbon (C7) sugars mannoheptulose and its corresponding alcohol, perseitol, may act as ripening inhibitors of avocado fruit while still on the tree and shortly after harvest. ${ }^{12,13}$ Avocados contain substantial amounts of C7 sugars with their concentrations declining during low temperature storage and dropping markedly during ripening. ${ }^{12-16}$ In accordance with these findings, Landahl et al. found greater concentrations of mannoheptulose in the apical part of the fruit, where mesocarp tissues were firmest. ${ }^{17}$ However, the absolute concentrations of $\mathrm{C} 7$ sugars may vary largely according to season, growing areas and transit time ${ }^{16,17}$ and the function, if any, of C7 sugars in controlling ripening is yet to be elucidated.

Exposure of avocado fruit to 1-MCP has been shown to effectively suppress or delay respiration rate, softening, colour change and cellulase activity ${ }^{18-22}$ and downregulate expression of ethylene-associated genes. ${ }^{1,3}$ Ethylene scavengers, on the other hand, are not as widely used, and research on the physiological effects of ethylene removal is scarce. Studies have shown that a newly developed palladium (Pd)-promoted ethylene scavenger $\left(\mathrm{e}^{\circledR}{ }^{\circledR}\right.$ Ethylene Remover) supported on zeolite effectively delayed ripening of avocado cv. Hass stored at $12^{\circ} \mathrm{C}{ }^{23,24}$ and $5^{\circ} \mathrm{C} .{ }^{15}$ However, a combination of these approaches has not been previously investigated. It is presumed by some that 1-

This article is protected by copyright. All rights reserved. 
MCP treated fruit overcome inhibition by synthesising new receptors ${ }^{25}$ and that fruit may regain sensitivity to ethylene. Hence, it might be expected that ethylene removal could further extend postharvest life of 1-MCP-treated fruit.

The present study addressed the effect of 1-MCP $\left(0.3 \mu \mathrm{L} \mathrm{L}^{-1}\right)$, e+ ${ }^{\circledR}$ Ethylene Remover and the combination thereof on ripening of imported avocado cv. Hass fruit stored for 7 days at $12^{\circ} \mathrm{C}$. The temporal changes in ethylene production, respiration, mesocarp C7 sugars and ABA concentrations, as measured using a newly developed LC-ESI-MS/MS method, were assessed and discussed in relation to differences in firmness and colour. The objectives of this work were two-fold: (i) to address the effect of combining ethylene removal and ethylene blocking on extending shelf life of avocado cv. Hass and (ii) to detail the biochemical and physiological changes in imported avocado fruit in an attempt to identify a biochemical marker, i.e. ABA or C7 sugars, which may explain heterogeneity in ripening and could be used as a potential indicator of fruit storability.

\section{MATERIALS AND METHODS}

\section{Plant material}

Mid-season pre-climacteric avocado cv. Hass fruit (size code 18, 200 g, 29\% dry matter content) were sourced from a commercial farm in White River (Mpumalanga, South Africa) and were supplied by Mack Multiples Division (M. W. Mack Ltd., Kent, U.K.). Avocados were harvested on 4-8th June and shipped to the UK under refrigeration $\left(5.5^{\circ} \mathrm{C}\right)$. Fruit were containerised by the grower, which ensured that the cool chain was maintained from harvest until arrival in the UK. Fruit arrived at the Plant Science Laboratory on 13th July and were hence 35-39 days old, which is not unusual for fruit imported into UK. Fruit were unripe upon arrival as confirmed by initial colour,

This article is protected by copyright. All rights reserved. 
firmness and ethylene production measurements. Fruit were not pre-treated with 1MCP.

\section{Treatments, storage conditions and sampling regime}

All treatments were carried out at $12^{\circ} \mathrm{C}$. Equal batches of fruit $(\mathrm{n}=42)$ were placed into water-sealed air tight polypropylene chambers $(88 \mathrm{~cm} \times 59 \mathrm{~cm} \times 59 \mathrm{~cm})$ which housed a $8 \mathrm{~cm} \times 8 \mathrm{~cm}$ electric fan (Nidec Beta SL, Nidec, Japan). Fruit were treated with $\mathrm{e}^{\circledR}{ }^{\circledR}$ Ethylene Remover $(\mathrm{n}=42), 1-\mathrm{MCP}\left(0.3 \mu \mathrm{L} \mathrm{L}^{-1}\right.$ for $\left.16 \mathrm{~h} ; \mathrm{n}=84\right)$ or un-treated $(\mathrm{n}=42)$. Treatment with e+ ${ }^{\circledR}$ Ethylene Remover was achieved by placing $32 \mathrm{~g}$ of powdered $\mathrm{e}+{ }^{\circledR}$ Ethylene Remover (metal loading of $1 \% \mathrm{Pd}(\mathrm{m} / \mathrm{m}))$ in Petri dishes $(\mathrm{n}=8)$ within the box. The material was not removed for the duration of the storage trial. 1-MCP gas was released from a commercial powdered formulation (SmartFresh; AgroFresh, Rohm and Haas Inc., Italy) containing $0.14 \%$ of active ingredient. A stock gas $\left(200 \mu \mathrm{L} \mathrm{L}^{-1}\right)$ was prepared by dissolving $1.2 \mathrm{~g}$ SmartFresh powder with $20 \mathrm{~mL}$ distilled water at $50^{\circ} \mathrm{C}$ in a $3 \mathrm{~L}$ sealed jar. To achieve the desired concentration $\left(0.3 \mu \mathrm{L} \mathrm{L}^{-1}\right)$, appropriate volumes of headspace were removed from the prepared concentrated stock and injected into experimental chambers using a syringe. The concentration of 1-MCP was quantified as previously described. ${ }^{15}$ Following 1-MCP application, all boxes were kept sealed for 16 $\mathrm{h}$ according to the manufacturer's recommendation (Regiroli G, pers.comm.). Fans placed within the boxes ensured homogenous distribution of the 1-MCP gas. Untreated fruit acted as controls and were held in the same conditions as treated fruit.

After $16 \mathrm{~h}, 1$-MCP-treated fruit $(\mathrm{n}=84)$ were further divided into two batches. To one batch was added $4 \mathrm{~g}$ of fresh $\mathrm{e}+{ }^{\circledR}$ Ethylene Remover $\left(1-\mathrm{MCP}+\mathrm{e}+{ }^{\circledR}\right.$ Ethylene Remover; $n=42)$ as described above and to the other batch was added nothing (1MCP; $\mathrm{n}=42$ ). In order to verify the effects of delaying application of $\mathrm{e}+{ }^{\circledR}$ Ethylene 
Remover by $16 \mathrm{~h}$, some additional fruit $(\mathrm{n}=42)$ were held as controls in a chamber for $16 \mathrm{~h}$ after which the ethylene scrubber was applied (delayed $\mathrm{e}+{ }^{\circledR}$ Ethylene Remover; $\mathrm{n}$ $=42$ ). Following treatments fruit were stored for 7 days at $12^{\circ} \mathrm{C}$. For the duration of the storage trial, $\mathrm{CO}_{2}$ build up was avoided by opening the boxes every $24 \mathrm{~h}$, coinciding with sampling time. $\mathrm{CO}_{2}$ levels inside boxes subsamples were monitored daily (before sampling) and averaged $1.13 \%$.

Samples $(n=6$ per treatment) were taken at days $1(24 \mathrm{~h}$ after treatments were completed), 2, 3, 4, 5 and 7 for respiration, ethylene production, firmness and colour assessment. Samples derived from days 1, 3 and 5 were prepared and analysed for sugars $(n=6$ per treatment $)$ and ABA $(n=3$ per treatment, except delayed e+ Ethylene Remover-treated fruit which were not analysed for ABA) concentration. A subsample of fruit was assessed upon arrival at the laboratory for firmness, colour, ethylene production, sugars $(n=6$, baseline $)$ and $\mathrm{ABA}(\mathrm{n}=3$, baseline $)$ content. In summary, the trial had 5 treatments, 6 sampling times and 6 fruit per replicate, which gave a total of 180 fruit, excluding baseline, analysed for physiological parameters. For sugars analysis, the trial had 5 treatments, 3 sampling times and 6 fruit per replicate, which gave a total of 90 fruit analysed, excluding baseline fruit. For ABA, 3 fruit replicates from 4 treatments and 3 sampling times were analysed, which gave a total of 36 fruit analysed, excluding baseline fruit.

\section{Respiration rate and ethylene production}

At each sampling interval, fruit ( $\mathrm{n}=6$ per treatment) were removed from chambers and placed individually in $3 \mathrm{~L}$ jars for $2 \mathrm{~h}$ at $12^{\circ} \mathrm{C}$ (storage temperature; $\mathrm{n}=3$ fruit) or $20^{\circ} \mathrm{C}$ (standard temperature; $\mathrm{n}=3$ fruit). After $2 \mathrm{~h}$, a headspace gas sample was removed using a syringe. Ethylene and $\mathrm{CO}_{2}$ were quantified by gas chromatography with flame

This article is protected by copyright. All rights reserved. 
ionisation detector (FID) and hot wire detector (HWD), respectively, as previously described. $^{15}$

\section{Firmness and colour measurement}

Objective colour (lightness; $\left.\mathrm{L}^{*}\right)$, chroma (colour saturation; $\left.\mathrm{C}^{*}\right)$, and hue angle $\left(\mathrm{H}^{\circ}\right)$ of each fruit was determined as previously described ${ }^{15}$ using a Minolta CR-400 colorimeter and DP-400 data processor (Minolta Co. Ltd., Japan). Firmness was determined after fruit internal core temperature had equilibrated to $c a .18^{\circ} \mathrm{C}$ using an Instron Uniaxial Testing Machine (model 5542, MA) fitted with an $8 \mathrm{~mm}$ diameter flat probe as described before. ${ }^{15}$

\section{Biochemical analysis}

\section{Reagents}

Sucrose, D-glucose, D-fructose and D-mannoheptulose standards were purchased from Sigma (Dorset, UK). Perseitol (D-glycero-D-galacto-heptitol) was obtained from Glycoteam (Glycoteam GmbH, Hamburg, Germany). All other chemicals used were of analytical grade and purchased from Fisher Scientific Chemicals unless otherwise stated (Leics., UK).

\section{Sample preparation}

After firmness measurement, fruit were cut in half vertically into two equal sections and prepared for subsequent biochemical analysis as previously described. ${ }^{15}$ Approximately $30 \mathrm{~g}$ of chopped and pooled mesocarp tissue sample was immediately snap-frozen in liquid nitrogen and held at $-40^{\circ} \mathrm{C}$ before being freeze-dried in the dark in a Christ ALPHA-RVC freeze-drier with cooling-trap ALPHA 1-4 (Christ, Osterode, Germany)

This article is protected by copyright. All rights reserved. 
for 7 days. Dry matter (DM) was determined and freeze-dried samples were ground to a fine powder before being returned to $-40^{\circ} \mathrm{C}$ storage. A defatted residue powder was prepared according to Meyer and Terry ${ }^{14}$ : briefly, $1 \mathrm{~g}$ of ground lyophilized mesocarp tissue was homogenised with hexane and filtered under vacuum through Fisherbrand QL 100 filter paper (Fisher Scientific, Leics., UK). The lipid-containing solvent was discarded and the powder residue was recovered from the filter paper. The recovered residue was weighed and stored at $-40^{\circ} \mathrm{C}$ for subsequent analysis of sugars and $\mathrm{ABA}$.

\section{Extraction and quantification of sugars}

Sugars were extracted from the defatted residue powder $(150 \mathrm{mg})$ with $62.5 \%(\mathrm{v} / \mathrm{v})$ aqueous methanol as described previously. ${ }^{14}$ Identification and quantification of sugars in the avocado extract were performed by high performance liquid chromatography (HPLC) as described before ${ }^{14}$ with slight modification; analysis was performed using an Agilent 1200 series HPLC binary pump system (Agilent, Berks., UK), equipped with a refractive index detector (RID, Agilent) G1362A and cooled autosampler set at $4^{\circ} \mathrm{C}$. The presence and abundance of fructose, glucose, sucrose, mannoheptulose and perseitol were automatically calculated by comparing sample peak area to standards of known concentration using ChemStation Rev. B.02.01.

\section{ABA extraction and quantification}

Defatted residue powder (50 mg) obtained after lipid extraction was extracted overnight in $5 \mathrm{~mL}$ of a solution of $80: 19: 1(\mathrm{v} / \mathrm{v} / \mathrm{v})$ acetone: water: acetic acid at $4^{\circ} \mathrm{C}$ in the dark on a suspension mixer. Extracted samples were vortexed and then centrifuged at $3000 \mathrm{rpm}$ for $10 \mathrm{~min}$. The supernatant was collected and the residue pellets were re-extracted with $1 \mathrm{~mL}$ fresh extraction solvent. The second extract was centrifuged and supernatants

This article is protected by copyright. All rights reserved. 
were combined. After dilution (1:25) of the extract with fresh solvent, $20 \mathrm{ng}$ of the deuterated internal standard (IS; $\mathrm{d}_{4}-\mathrm{ABA}$, National Research Council of Canada, Saskatchewan, Canada) was added from a concentrated stock solution. The dilution factor and amount of IS required for accurate results were determined by preliminary experiments. The solution was then filtered through a syringe filter $(0.2 \mu \mathrm{m}$ pore diameter; Millipore Corp., MA, USA). The solvent was evaporated to dryness under vacuum at $4^{\circ} \mathrm{C}$ in the dark. Dried extracts were re-suspended in $3 \mathrm{~mL}$ HPLC-grade water and purified by loading extracts onto a Sep-Pak C18 SPE cartridge (Waters, Herts., UK) under gentle vacuum to remove more polar compounds. The eluted fraction was taken to dryness under vacuum at $4^{\circ} \mathrm{C}$ and kept at $-40^{\circ} \mathrm{C}$ until further analysis. Lyophilised samples were re-suspended in $500 \mu \mathrm{L}$ methanol prior to injection.

Samples were analysed using a Waters Alliance 2795 HPLC coupled to a Micromass Quattro quadrupole tandem mass spectrometer (Waters, MA, USA) with an electrospray ion source. Both the HPLC and the mass spectrometer were operated by MassLynx v4.0 SP3 software (Waters). Samples (10 $\mu \mathrm{L})$ were separated on a Zorbax Eclipse XDB-C18 analytical column (3.5 $\mu \mathrm{m}, 2.1$ x $100 \mathrm{~mm}$, Agilent, CA, USA) with 1 mm C18 guard column (Optiguard, Optimize Technologies, OR, USA) maintained at $25^{\circ} \mathrm{C}$. The mobile phase consisted of HPLC-grade methanol (A), water (B) and 5\% acetic acid (C). The gradient involved an increase/decrease in solvent $\mathrm{A} ; 10-60 \%, 15$ $\min ; 60-99.2 \%, 15 \mathrm{~min} ; 99.2-10 \%, 2 \mathrm{~min} ; 10 \%, 3 \mathrm{~min}$, at a constant proportion of solvent $\mathrm{C}(0.8 \%)$ at a flow rate of $0.2 \mathrm{~mL} \mathrm{~min}^{-1}$. Mass spectrometry was carried out using multiple reaction monitoring in negative ionisation mode, with a capillary potential of $2.75 \mathrm{kV}$, a source temperature of $120^{\circ} \mathrm{C}$, a desolvation temperature of $350^{\circ} \mathrm{C}$; cone gas and desolvation gas flow rates of 50 and $950 \mathrm{~L} \mathrm{~h}^{-1}$, respectively, and a collision gas (Ar) pressure of $5 \times 10^{-3}$ mbar. The multiple reaction monitoring (MRM)

This article is protected by copyright. All rights reserved. 
transitions were $263>153$ for $A B A$ and $267>156$ for $d_{4}-A B A$, with a cone voltage of 30 and $25 \mathrm{~V}$, respectively, and a collision energy of $9 \mathrm{eV}$ for both compounds. The retention time was 18.00 min for $\mathrm{ABA}$ and also for the IS $\mathrm{d}_{4}-\mathrm{ABA}$.

Calibration curves were prepared using a range of standard solutions containing an increasing amount of ABA with a constant amount of $\mathrm{d}_{4}-\mathrm{ABA}$. The area beneath the MRM product ion peak was determined for the analyte and IS, and the response calculated according to the formula: Response $=$ analyte product ion peak area $\mathrm{x}$ ([IS]/IS product ion peak area), where the [IS] is the known concentration of IS added. Concentration of $\mathrm{ABA}$ in samples was quantified in relation to the internal standard using the calibration curves generated.

\section{Statistical analysis}

All statistical analyses were carried out using Genstat for Windows vers. 10 (VSN International Ltd., Herts., UK) unless otherwise stated. Data were subjected to analysis of variance (ANOVA). Least significant difference values (LSD; $P=0.05$ ) were calculated for mean separation using critical values of $t$ for two-tailed tests. Since respiration rate was affected by temperature, analysis of respiration rate was carried out at $12^{\circ} \mathrm{C}$ and $20^{\circ} \mathrm{C}$ separately. Tests for correlations between mean values for physical parameters ( $\mathrm{H}^{\mathrm{o}}$ and firmness), ethylene production, respiration rate, sugars and $\mathrm{ABA}$ were made using Pearson's product moment correlation. Correlations are presented with the Pearson's correlation coefficient (r) and $P$ value based on a two- tailed test. Unless otherwise stated significant differences were $P<0.05$. Means with different letters in tables are significantly different $(P<0.05)$. Firmness data was log transformed to fit the requirements for analysis of variance. Data presented are back transformed values that represent biological data. Non-linear regression against an exponential standard curve

This article is protected by copyright. All rights reserved. 
was used to model the change in firmness against ABA concentration and ethylene production.

\section{RESULTS AND DISCUSSION}

\section{Ethylene levels within storage chambers}

In the present study, concentrations of ethylene within boxes containing controls and 1MCP-treated fruit were above sub-physiologically active level of $0.1 \mu \mathrm{L} \mathrm{L}^{-1}$ during the 7 days of storage (Figure 1). However, addition of the ethylene scavenger reduced ethylene concentrations to below $0.1 \mu \mathrm{L} \mathrm{L}^{-1}$ for the first 2 days, after which concentrations were between $0.1-0.2 \mu \mathrm{L} \mathrm{L}^{-1}$. The combination of 1-MCP and $\mathrm{e}^{\circledR}$ Ethylene Remover treatments had the lowest ethylene concentrations, with concentrations below $0.1 \mu \mathrm{L} \mathrm{L}^{-1}$ for the entire duration of the storage trial.

The majority of research on avocado has been conducted on home-grown fruit treated or ripened shortly after harvest. However, there is a lack of research on postharvest quality of imported fruit. Most avocado fruit consumed in Europe are imported, and although fruit are shipped at a pre-climacteric stage and at low temperature, it is likely that biochemical changes occur during transit which affect subsequent ripening and quality. Therefore, using imported fruit with varied biological age in the present study better reflects commercial practice.

Rigorous control of ethylene concentration or inhibiting its action is fundamental to maintaining postharvest quality of climacteric commodities. For avocado, ethylene blocking can be achieved by using 1-MCP. ${ }^{18-22,26}$ In contrast, ethylene removal has been much less well studied. Previous work has shown that a Pd-promoted ethylene scavenger $\left(\mathrm{e}+{ }^{\circledR}\right.$ Ethylene Remover) had the ability to reduce ethylene levels below 
physiologically active concentrations and accordingly maintain better quality of imported avocado cv. Hass stored at $12^{\circ} \mathrm{C}{ }^{23,24}$ and $5^{\circ} \mathrm{C} .^{15}$

It is presumed by some that 1-MCP treated fruit overcome inhibition by synthesising new receptors and that fruit may eventually regain sensitivity to ethylene. ${ }^{18,25}$ In addition, Zhang et al. reported that mid-climacteric ' Booth 7' avocado fruit (7 d after harvest, ethylene production $65 \%$ of maximum) lost sensitivity to 1-MCP treatment. ${ }^{27}$ Present results suggest that ethylene scavenging can help further control ethylene in storage atmosphere of 1-MCP-treated fruit.

\section{INSERT FIGURE 1}

\section{Physiological parameters: Respiration rate, ethylene production, firmness and colour}

Upon arrival to laboratory (baseline), fruit firmness was $196.0 \pm 50.8 \mathrm{~N}$ and ethylene production was $0.96 \pm 0.94 \mu \mathrm{L} \mathrm{kg}^{-1} \mathrm{~h}^{-1}$, indicating that fruit were preclimacteric prior to treatments ${ }^{21}$. Respiration and ethylene production rates were measured at $12^{\circ} \mathrm{C}$ (storage temperature, $\mathrm{n}=3$ ) or $20^{\circ} \mathrm{C}$ (standard temperature, $\mathrm{n}=3$ ). The respiration rates recorded are presented in Table 1 and were in the range of those documented by others. ${ }^{28,29}$ There was a significant difference between respiration rates at different temperatures. At $12^{\circ} \mathrm{C}$, the overall respiration rate increased significantly between days 1 and 2, and all fruit exhibited a maximum between days 4-5, except for fruit treated with delayed application of $\mathrm{e}^{\circledR}{ }^{\circledR}$ Ethylene Remover which showed a maximum rate at day 7 (Table 1). The overall mean was significantly higher in controls vs. ${ }^{\circledR}{ }^{\circledR}$ Ethylene Remover -, 1-MCP- and 1-MCP $+\mathrm{e}+{ }^{\circledR}$ Ethylene Remover -treated fruit whilst delayed $\mathrm{e}^{\circledR}{ }^{\circledR}$ Ethylene Remover fruit were not different from any other

This article is protected by copyright. All rights reserved. 
treatment (Table 1). When respiration rate was measured at $20^{\circ} \mathrm{C}$, there was no significant effect of storage time or treatment, and the overall respiration rates increased from $43.4 \mathrm{~mL} \mathrm{~kg}^{-1} \mathrm{~h}^{-1}$ (day 1) to a maximum value of $58.4 \mathrm{~mL} \mathrm{~kg}^{-1} \mathrm{~h}^{-1}$ at day 5 .

There was no significant effect of temperature on ethylene production and therefore data for both $12^{\circ} \mathrm{C}$ and $20^{\circ} \mathrm{C}$ respiration trials were pooled (Table 2). Concentrations increased significantly during storage with a maximum at day 7 for all treatments. The maxima recorded (range 12.8-29.2 $\mu \mathrm{L} \mathrm{kg}^{-1} \mathrm{~h}^{-1}$ ) was relatively low compared with that reported in fruit ripened around $20^{\circ} \mathrm{C} .^{5}$ This could be explained by the lower storage temperature $\left(12^{\circ} \mathrm{C}\right)$ used presently, which probably accounted for differences in ethylene production behaviour, as reported before, ${ }^{29,30}$ or that the sampling intervals missed the peak production in ethylene, since different fruit of different biological age were used. Ethylene production was significantly affected by treatments, whereby overall mean ethylene production by fruit treated with 1-MCP and, to a greater extend, 1-MCP $+\mathrm{e}+{ }^{\circledR}$ Ethylene Remover, was significantly lower than that of controls (Table 2). Ethylene production by fruit treated with $\mathrm{e}^{\circledR}{ }^{\circledR}$ Ethylene Remover (delayed or not) was not significantly different from that of control or 1-MCP-treated fruit. The standard error in respiration and ethylene production rates for 1-MCP-treated fruit was proportionally greater than for any other treatments (Table 1 and 2), indicating more heterogeneity in these parameters for these fruit. Heterogeneity in ripening of avocado fruit treated with $1-\mathrm{MCP}$ is not unusual. ${ }^{31}$

The firmness (Table 3) and hue angle $\left(\mathrm{H}^{\mathrm{o}}\right.$, Table 4) of all avocado fruit decreased significantly over time, from an initial value of $196.0 \mathrm{~N}$ and 118.22, respectively, upon arrival (baseline) to an average value of $8.5 \mathrm{~N}$ and 65.5, respectively, after 7 days at $12^{\circ} \mathrm{C}$, indicating full ripeness. Controls generally softened faster than treated fruit and were already ripe $(<20 \mathrm{~N})$ after 3 days storage (Table 3$)$. Consistent with a reduction in 
atmospheric ethylene to below $0.1 \mu \mathrm{L} \mathrm{L}^{-1}$, treatment with $\mathrm{e}^{\circledR}{ }^{\circledR}$ Ethylene Remover and delayed $\mathrm{e}^{\circledR}{ }^{\circledR}$ Ethylene Remover retained a significantly $(\mathrm{p}<0.05)$ higher firmness over the first 3 days, after which fruit softened similarly to controls. These fruit also exhibited higher, although not significantly, hue angle compared with control (Table 4). As expected, treatment with 1-MCP $+\mathrm{e}+{ }^{\circledR}$ Ethylene Remover, and to a lesser extent 1MCP alone, resulted in the best maintenance of firmness (average $56.0 \mathrm{~N}$ and $67.6 \mathrm{~N}$, respectively; Table 3) and greenness (average $\mathrm{H}^{\circ} \sim 100.50$ and 101.98, respectively; Table 4) over storage time ( $p<0.05$ vs. controls). These fruit attained ripe stage $(<20 \mathrm{~N})$ only at day 7 . Lightness $\left(\mathrm{L}^{*}\right)$ and chroma $\left(\mathrm{C}^{*}\right)$ of the peel decreased significantly over time, from 36.18 to 29.83 and from 20.66 to 11.89 , respectively, but were not affected by treatment applied (data not shown).

1-MCP has already been shown to delay the ethylene catalytic production and the ripening of avocado fruit ${ }^{18-22}$ and, recently, ethylene scavenging also demonstrated to slow down ripening of avocado cv. Hass. ${ }^{15,23}$ However, it is the first time that the effects of combining 1-MCP and ethylene scavenging for extending shelf life of avocado fruit is reported. It was observed that $1-\mathrm{MCP}$ treatment did not completely inhibit ethylene biosynthesis, as demonstrated by ethylene production by these fruit (Table 2) and is in accordance with the start of softening (albeit at lower rate) already after 2 days storage in these fruit. It is believed that the ethylene antagonist binds irreversibly to the ethylene receptors and that plants may overcome inhibition by producing new receptors and thus regain sensitivity to the hormone. ${ }^{18,25,32}$ It was also reported that once ripening is initiated (mid-climacteric state), avocado loose sensitivity to 1-MCP treatment ${ }^{27}$ and thus ethylene perception and quality loss may occur in these fruit. Although it is acknowledged that 1-MCP was applied after transit and not immediately after harvest in our study, highest quality maintenance found in fruit treated with $1-\mathrm{MCP}+\mathrm{e}^{\circledR}$ 
Ethylene Remover as compared with 1-MCP only suggest that removing ethylene may suppress further ethylene perception and consequently may delay ethylene production and ripening of 1-MCP-treated fruit.

\author{
INSERT TABLE 1 \\ INSERT TABLE 2 \\ INSERT TABLE 3 \\ INSERT TABLE 4
}

\title{
Sugars
}

It was previously postulated that C7 sugars metabolism may contribute to controlling the ripening process in avocado, since a drop in their concentration appeared to be a physiological pre-requisite for softening to occur. ${ }^{12}$ These non-structural carbohydrates have been shown to decline during the season, during cold storage and as fruit ripen. ${ }^{13,15,16,33,34}$ In addition, Blakey et al. recently reported that South African fruit that ripened slower (12-13 days) had higher mannoheptulose content at harvest than fast ripening fruit (6-7 days). ${ }^{35}$

In agreement with others, ${ }^{12,13,15-17}$ sucrose and the heptose sugars, mannoheptulose and perseitol, were the major sugars measured in all samples, and were present at concentrations of $15.4 \mathrm{mg} \mathrm{g}^{-1} \mathrm{DM}, 35.6 \mathrm{mg} \mathrm{g}^{-1} \mathrm{DM}$ and $18.7 \mathrm{mg} \mathrm{g}^{-1} \mathrm{DM}$, respectively, before storage. Glucose and fructose were detected but concentrations were at the limit of quantification, hence these sugars were not considered in this study. Sugars varied differently with storage time, whereby mannoheptulose followed a predictable and significant $(\mathrm{p}<0.05)$ decrease of 1.5 -fold during ripening, from $43.8 \mathrm{mg} \mathrm{g}^{-1} \mathrm{DM}$ at day 1

This article is protected by copyright. All rights reserved. 
storage to $28.4 \mathrm{mg} \mathrm{g}^{-1} \mathrm{DM}$ after 5 days (Table 5). In contrast, perseitol and sucrose content remained constant over time.

C7 sugars have been implicated, not only as ripening inhibitor, but also as respiratory substrate. ${ }^{33,34}$ All nutrients required for the high energy-demanding respiration and ethylene production are likely to come from carbohydrates reserves within the fruit, which in avocado are constituted mainly by C7 sugars. ${ }^{13,33}$ Therefore, it is expected that differences in respiration rate according to treatments would have affected carbohydrate utilization, and hence C7 sugars content. However, in the present study, treatment had no effect on sugar concentrations in the fruit mesocarp (Table 5) and therefore the role of $\mathrm{C} 7$ sugars as a substrate for respiration and ethylene production in avocado cv. Hass remains uncertain and warrant further research.

\title{
INSERT TABLE 5
}

\begin{abstract}
Abscisic acid
Endogenous plant hormones are known to play a vital role in fruit growth and development, and changes in their ratios also occur during ripening/senescence. Avocado contains ABA and the importance of the hormone for avocado fruit quality has been previously highlighted. ${ }^{6}$ In this study, ABA was successfully extracted and quantified using a newly developed LC-ESI-MS/MS method and concentrations measured (Table 6) were in the same range as that measured in South African fruit by radioimmunoassay. ${ }^{6}$
\end{abstract}

The initial ABA content prior to treatments application was $1081 \mathrm{ng} \mathrm{g}^{-1}$ residue (454 ng $\mathrm{g}^{-1} \mathrm{DM} ; 124.6 \mathrm{ng} \mathrm{g}^{-1}$ fresh matter (FM)), and the concentration increased significantly during storage for all treatments (Table 6). There was a treatment main

This article is protected by copyright. All rights reserved. 
effect as controls contained overall significantly more ABA (2480 $\mathrm{ng} \mathrm{g}^{-1}$ residue) than treated fruit. Also, fruit treated with $\mathrm{e}^{+}{ }^{\circledR}$ Ethylene Remover had overall significantly more ABA (1929 $\mathrm{ng} \mathrm{g}^{-1}$ residue) than those treated with 1-MCP-treated (1584 $\mathrm{ng} \mathrm{g}^{-1}$ residue) and 1-MCP $+\mathrm{e}^{+}{ }^{\circledR}$ Ethylene Remover -treated fruit (1443 $\mathrm{ng} \mathrm{g}^{-1}$ residue). There was a significant interaction between storage time and treatments (Table 6) whereby 1MCP-treated fruit at day 1 contained significantly less ABA vs. all other fruits. After 3 days, fruit treated with 1-MCP $+\mathrm{e}+{ }^{\circledR}$ Ethylene Remover, which were also the firmest fruits, had accumulated less ABA than 1-MCP-treated $(\mathrm{p}<0.05)$ and $\mathrm{e}^{\circledR}{ }^{\circledR}$ Ethylene Remover -treated $(\mathrm{p}>0.05)$ fruit, whilst controls, which were the softest fruit, exhibited highest ABA levels ( $\mathrm{p}<0.05$ vs. all other treatments). After 5 days, both controls and e $+{ }^{\circledR}$ Ethylene Remover -treated fruit displayed significantly higher ABA levels compared with 1-MCP and 1-MCP $+\mathrm{e}+{ }^{\circledR}$ Ethylene Remover -treated fruits.

\section{INSERT TABLE 6}

Large amounts of ABA have been previously reported in unripe, freshly harvested fruit $^{5}$ and it is known that ABA content in avocado flesh increases as the season progress. ${ }^{6}$ The observed rise in ABA concentrations as fruit softened was also observed in previous studies. ${ }^{4,5,6}$ Nevertheless, the present data bring novel insight into ABA since concentrations were significantly affected by blocking and/or removing ethylene, with the highest concentrations recorded in control fruit and the lowest in 1-MCP $+\mathrm{e}+{ }^{\circledR}$ Ethylene Remover -treated fruit.

In order to further describe the relationship between $\mathrm{ABA}$ and physiological ripening parameters, tests for correlations between mean values for physical parameters, ethylene production, respiration rate, sugars and ABA were made.

This article is protected by copyright. All rights reserved. 


\section{Correlation between physiological and biochemical variables}

There was generally a significant and good correlation between firmness and $\mathrm{H}^{\mathrm{o}}(\mathrm{r}=$ 0.72) indicating coordination in the ripening event. As expected, there was also a negative correlation between the ethylene production, and firmness and greenness $(\mathrm{r}=$ 0.59 and $\mathrm{r}=-0.70$, respectively). However, firmness, $\mathrm{H}^{\mathrm{o}}$ and ethylene production were weakly correlated with respiration rate and sugars content. The ABA concentration exhibited a negative correlation with firmness $(r=-0.69), H^{\circ}(r=-0.82)$ and a weak but positive correlation with ethylene production $(\mathrm{r}=0.56)$. In contrast, ABA was poorly correlated with sugars and respiration rate.

In order to further describe the relationship between ethylene production $(x)$ and softening $(y)$, non-linear regression was applied to the data. The relationship was well described by an exponential decay curve $y=a \exp (-b x)$ (Figure 2A), with a correlation coefficient of $r=0.87$ (coefficient of determination $r^{2}=0.76$ ). The same equation was found to describe the relationship between $\mathrm{ABA}(x)$ and softening $(y)$ with a correlation coefficient of $r=0.78$ (coefficient of determination $r^{2}=0.61$ ) (Figure 2B).

\section{INSERT FIGURE 2}

Poor correlation between $\mathrm{C} 7$ sugars and physiological ripening parameters in avocado cv. Hass has been reported recently by Pedreschi et al. ${ }^{36}$ Using a methodology of fruit biopsy, authors found no correlation of either mannoheptulose, perseitol or C7 sugars with time to reach edible ripeness. Meyer and Terry ${ }^{15}$ observed that firmer fruit, as treated with 1-MCP or e $+{ }^{\circledR}$ Ethylene Remover, contained more mannoheptulose and perseitol than untreated fruit, yet the same study found that metabolism of C7 sugars

This article is protected by copyright. All rights reserved. 
was not always systematically related to the ripening process since late season fruit treated with e+ Ethylene Remover and 1-MCP treatments took longer to ripen than did controls and this in spite of quasi-absence of mannoheptulose in the mesocarp tissue. Although it is acknowledged that present experimental conditions were different from that in other studies in terms of fruit origin and ripening regime, which may have accounted for discrepancies, the absence of correlation between $\mathrm{C} 7$ sugars and ripening parameters seen herein suggest that there is still uncertainty as to the role of C7 sugar metabolism in avocado fruit and more systematic research would be required to fully elucidate their function. Hershkovitz et al. highlighted a possible role for the seed in delaying fruit ripening process of avocado cv. Arad. ${ }^{3,37}$ Also, a recent metabolic analysis of avocado Hass fruit during postharvest ripening revealed that several metabolites, mainly amino acids, were related to ripening heterogeneity and therefore could be potential biomarkers of fruit ripening. ${ }^{36}$

The present study found that treatment with 1-MCP $+\mathrm{e}^{+}{ }^{\circledR}$ Ethylene Remover, 1$\mathrm{MCP}$, and to a lesser extend $\mathrm{e}+{ }^{\circledR}$ Ethylene Remover, resulted in lower ABA content, reduced ethylene production and, consequently, delayed ripening. This suggests that ABA metabolism may to some degree be sensitive to ethylene blocking and thus is unlikely to have direct, ethylene-independent effects on ripening.

Correlations showed that ABA concentration was positively correlated with endogenous ethylene production (although not with respiration) and negatively correlated with firmness. It should be noted that in the present study, only the free form of $\mathrm{ABA}$ was quantified. $\mathrm{ABA}$ action not only depends on its concentration but is also related to the activity of signal receptors of ABA. ${ }^{38}$ Nevertheless, this suggests that ABA may be to some degree related to endogenous ethylene. The nature of the interaction between ethylene and ABA is, however, far from understood. Based on the 
literature, it is more plausible that a reduction in ABA concentration, via inhibited ethylene action, could have in turn affected ethylene biosynthesis and/or ripening. Indeed, it has been suggested that ABA stimulates ethylene biosynthesis by enhancing ACC synthesis. ${ }^{39,40}$ ABA may also cause alteration of tissue sensitivity to ethylene. ${ }^{41}$ In 'Granny Smith' apples, Lara and Vendrell ${ }^{10}$ suggested that an increase in endogenous ABA concentration may precede the increase in ethylene responsiveness, although it was not clarified how this $\mathrm{ABA}$ increase promoted sensitivity to ethylene.

Yet, whether ABA induces fruit ripening and whether this is achieved via a direct action on ethylene biosynthesis in avocado, or indirect effect by enhancing tissue responsiveness remains unknown. There is a general consensus that $\mathrm{ABA}$ and ethylene may act synergistically, with different importance according to the developmental stage of the fruit. ${ }^{9}$ Fully elucidating the nature of the interaction between ethylene and ABA would require more research.

\section{CONCLUSION}

The purposes of the present study were to (i) investigate the effects of ethylene removal, ethylene blocking and the combination thereof on maintaining quality of imported avocado cv. Hass fruit and (ii) to assess whether C7 sugars and ABA plays a role in the regulation of ripening. This study demonstrated that effectively removing ethylene can help further to control ethylene and mitigate undesirable ripening due to ethylene sensitivity regain, which may occur in 1-MCP-treated fruit

Using 1-MCP and/or $\mathrm{e}^{\circledR}{ }^{\circledR}$ Ethylene Remover as model treatments to modulate ethylene-response pathways, differences in endogenous ABA content and in fruit physiology were observed, substantiating that ABA is associated with ethylene. However, whether ABA directly induces ethylene synthesis in imported avocado fruit, 
or alters the sensitivity of tissue to ethylene remains unclear. An investigation of ABA and its metabolites at the genetic level would be useful for improving understanding of the interaction between $\mathrm{ABA}$ and ethylene in avocado ripening.

\section{ACKNOWLEDGEMENTS}

The authors thank Johnson Matthey Plc. and Anglo Platinum for financial support and Mack Multiples Division (M. W. Mack Ltd., Kent, U.K) for supplying avocado fruit. AgroFresh Inc. are thanked for supplying 1-MCP. Thanks are given to Mrs. Balwinder Cook and Mr. Allen Hilton for technical support and Mrs. Patricia Bellamy for statistical advice.

\section{REFERENCES}

1. Owino WO, Nakano R, Kubo Y and Inaba A, Differential regulation of genes encoding ethylene biosynthesis enzymes and ethylene response sensor ortholog during ripening and in response to wounding in avocados. J Amer Soc Hort Sci 27:520-527 (2002).

2. Cara B and Giovannoni JJ, Molecular biology of ethylene during tomato fruit development and maturation. Plant Science 175:106-113 (2008).

3. Hershkovitz V, Friedman H, Goldschmidt EE and Pesis E, Ethylene regulation of avocado ripening differs between seeded and seedless fruit. Postharvest Biol Technol 56: 138-146 (2010).

This article is protected by copyright. All rights reserved. 
4. Chernys JT and Zeevaart, JAD. Characterization of the 9-cis-epoxycarotenoid dioxygenase gene family and the regulation of abscisic acid biosynthesis in avocado. Plant Physiol 124:343-53 (2000).

5. Adato I, Gazit S and Blumenfeld A, Relationship between changes in abscisic acid and ethylene production during ripening of avocado fruit. Aust J Plant Physiol 3:555-558 (1976).

6. Cutting JG, Bower JP and Wolstenholme BN, Stress, delayed harvest and fruit quality in Fuerte avocado fruit. S Afr Avocado Grow Assoc Yrb 9:39-42 (1986).

7. Richings E, Cripps R and Cowan A, Factors affecting 'Hass' avocado fruit size: carbohydrate, abscisic acid and isoprenoid metabolism in normal and phenotypically small fruit. Physiol Plantarum 109:81-89 (2000).

8. Blakey RJ, Bower JP and Bertling I, Influence of water and ABA supply on the ripening pattern of avocado (Persea americana Mill.) fruit and the prediction of water content using Near Infrared Spectroscopy. Postharvest Biol Technol 53:7276 (2009).

9. Zhang M, Leng P, Zhang G and Li X, Cloning and functional analysis of 9-cisepoxycarotenoid dioxygenase (NCED) genes encoding a key enzyme during abscisic acid biosynthesis from peach and grape fruits. J Plant Physiol 166:12411252 (2009).

This article is protected by copyright. All rights reserved. 
10. Lara I and Vendrell M, Development of ethylene-synthesizing capacity in preclimacteric apples: interaction between abscisic acid and ethylene. J Amer Soc Hort Sci 125:505-512 (2000).

11. Zaharah SS, Singh Z, Symons GM and Reid JB. Mode of action of abscisic acid in triggering ethylene biosynthesis and softening during ripening in mango fruit. Postharvest Biol Technol 75: 37-44 (2013).

12. Liu X, Sievert J, Arpaia ML and Madore MA, Postulated physiological roles of the seven-carbon sugars, mannoheptulose, and perseitol in avocado. J Amer Soc Hort Sci 127:108-114 (2002).

13. Liu X, Robinson PW, Madore MA, Witney GW and Arpaia ML, 'Hass' avocado carbohydrate fluctuations. II. Fruit growth and ripening. J Amer Soc Hort Sci 124:676-681 (1999).

14. Meyer MD and Terry LA, Development of a rapid method for the sequential extraction and subsequent quantification of fatty acids and sugars from avocado mesocarp tissue. J Agric Food Chem 56:7439-7445 (2008).

15. Meyer MD and Terry LA, Fatty acid and sugar composition of avocado, cv. Hass, in response to treatment with an ethylene scavenger or 1-methylcyclopropene to extend storage life. Food Chem 121:1203-1210 (2010).

This article is protected by copyright. All rights reserved. 
16. Donetti M and Terry LA, Biochemical markers defining growing area and ripening stage of imported avocado fruit cv. Hass. J Food Compos Anal 34:90-98 (2014).

17. Landahl S, Meyer MD and Terry LA, Spatial and temporal analysis of textural and biochemical changes of imported avocado cv. Hass during fruit ripening. J Agric Food Chem 57:7039-7047 (2009).

18. Feng X, Apelbaum A, Sisler EC and Goren R, Control of ethylene responses in avocado fruit with 1-methylcyclopropene. Postharvest Biol Technol 20:143-150 (2000).

19. Jeong J, Huber DJ and Sargent SA, Influence of 1-methylcyclopropene (1- MCP) on ripening and cell-wall matrix polysaccharides of avocado (Persea americana) fruit. Postharvest Biol Technol 25:241-256 (2002).

20. Jeong J, Huber DJ and Sargent SA, Delay of avocado (Persea american) fruit ripening by 1-methylcyclopropene and wax treatments. Postharvest Biol Technol 28:247 -257 (2003).

21. Jeong $\mathrm{J}$ and Huber DJ, Suppression of avocado (Persea americana Mill.) fruit softening and changes in cell wall matrix polysaccharides and enzyme activities: differential responses to $1-\mathrm{MCP}$ and delayed ethylene application. J Amer Soc Hort Sci 129:752-759 (2004).

This article is protected by copyright. All rights reserved. 
22. Hershkovitz V, Saguy, SI and Pesis E, Postharvest application of 1-MCP to improve the quality of various avocado cultivars. Postharvest Biol Technol 37:252-264 (2005).

23. Terry LA, Ilkenhans T, Poulston S, Rowsell L and Smith AWJ, Development of new palladium-promoted ethylene scavenger. Postharvest Biol Technol 45:214220 (2007).

24. Smith AWJ, Poulston S, Rowsell L, Terry LA and Anderson JA, A new Palladium-based ethylene scavenger to control ethylene-induced ripening of climacteric fruit. Platinum Metals Rev 53:112-122 (2009).

25. Jiang Y, Joyce DC and Macnish AJ, Extension of the shelf life of banana fruit by 1-methylcyclopropene in combination with polyethylene bags. Postharvest Biol Technol 6:187-193 (1999).

26. Watkins $\mathrm{CB}$, The use of 1-methylcyclopropene (1-MCP) on fruits and vegetables. Biotechnol Adv 24:389-409 (2006).

27. Zhang Z, Huber DJ and Rao J, Ripening delay of mid-climacteric avocado fruit in response to elevated doses of 1-methylcyclopropene and hypoxia-mediated reduction in internal ethylene concentration. Postharvest Biol Technol 60:83-91 (2011).

This article is protected by copyright. All rights reserved. 
28. Adato I and Gazit S, Changes in the initiation of climacteric ethylene in harvested avocado fruits during their development. J Sci Food Agri 28: 240-242 (1977).

29. Perez K, Mercado J and Soto-Valdez H, Note. Effect of storage temperature on the shelf life of Hass avocado (Persea americana). Food Sci Technol Int 10:73-77 (2004).

30. Zamorano JP, Dopica B, Lowe AL, Wilson ID, Grierson D and Merodio C, Effect of low temperature storage and ethylene removal on ripening and gene expression changes in avocado fruit. Postharvest Biol Technol 4:331-342 (1994).

31. Ochoa-Ascencio S, Hertog MLATM, Nicolaï BM, Modelling the transient effect of 1-MCP on 'Hass' avocado softening: A Mexican comparative study. Postharvest Biol Technol 51:62-72 (2009).

32. Sisler EC, Dupille E and Serek M, Effect of 1-methylcyclopropene, and methylenecyclopropane on ethylene binding and ethylene action on cut carnations. Plant Growth Regul 18: 79-86 (1996).

33. Bertling I and Bower JP, Sugars as energy sources - is there a link to avocado fruit quality? S Afr Avocado Grow Assoc Yrb 28:38-39 (2005)

34. Tesfay SZ, Bertling I, Bower JP and Lovatt CJ. The quest for the function of 'Hass' avocado carbohydrates: clues from fruit and seed development as well as seed germination. Aust J Bot 60:79-86 (2012)

This article is protected by copyright. All rights reserved. 
35. Blakey RJ , Tesfay SZ, Bertling I and Bower JP, Changes in sugars, total protein, and oil in 'Hass' avocado (Persea americana Mill.) fruit during ripening. J Hort Sci Biotech 87:382-397 (2012).

36. Pedreschi R, Muñoz P, Robledo P, Becerra C, Defilippi BG, van Eekelen H, Mumm R, Westra E and de Vos RCH, Metabolomics analysis of postharvest ripening heterogeneity of 'Hass' avocadoes. Postharvest Biol Technol 92:172-179 (2014).

37. Hershkovitz V, Friedman H, Goldschmidt EE, Feygenberg O and Pesis E, Effect of seed on ripening-control components during avocado fruit development. J Plant Physiol 168: 2177-2183 (2011).

38. Zhang ZL, Chen $\mathrm{J}$ and Zhang DP, The abscisic acid binding proteins and their properties in grapevine fruits. Chin J Biochem Mol Biol 38:930-935 (1996).

39. Riov J, Dagan E, Goren R and Yang SF, Characterization of abscisic acid-induced ethylene production in citrus leaf and tomato fruit tissues. Plant Physiol 92:48-53 (1990).

40. Goren R, Dagan E, Sagee O, Riov J and Yang SF, Abscission in citrus leaf explants: role of ABA-induced ethylene. Acta Hortic 329:43-50 (1993).

This article is protected by copyright. All rights reserved. 
41. Bower JP and Cutting JG, Avocado fruit development and ripening physiology, in Horticultural Reviews, vol 10, ed. by Janick J. Timber Press, Portland, OR, pp. 229-271 (1988).

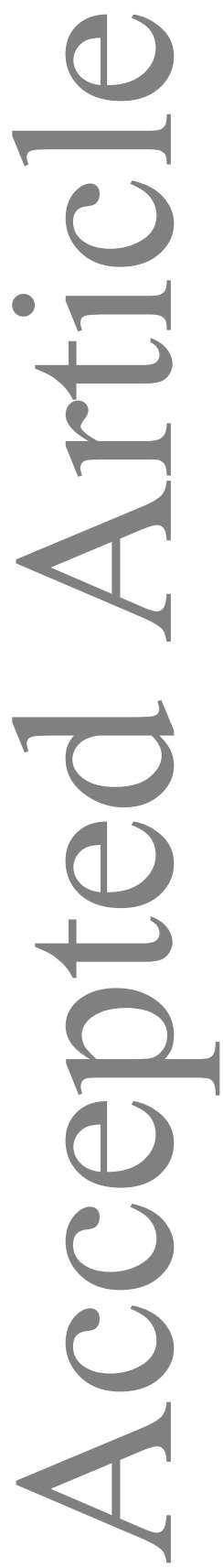

This article is protected by copyright. All rights reserved. 


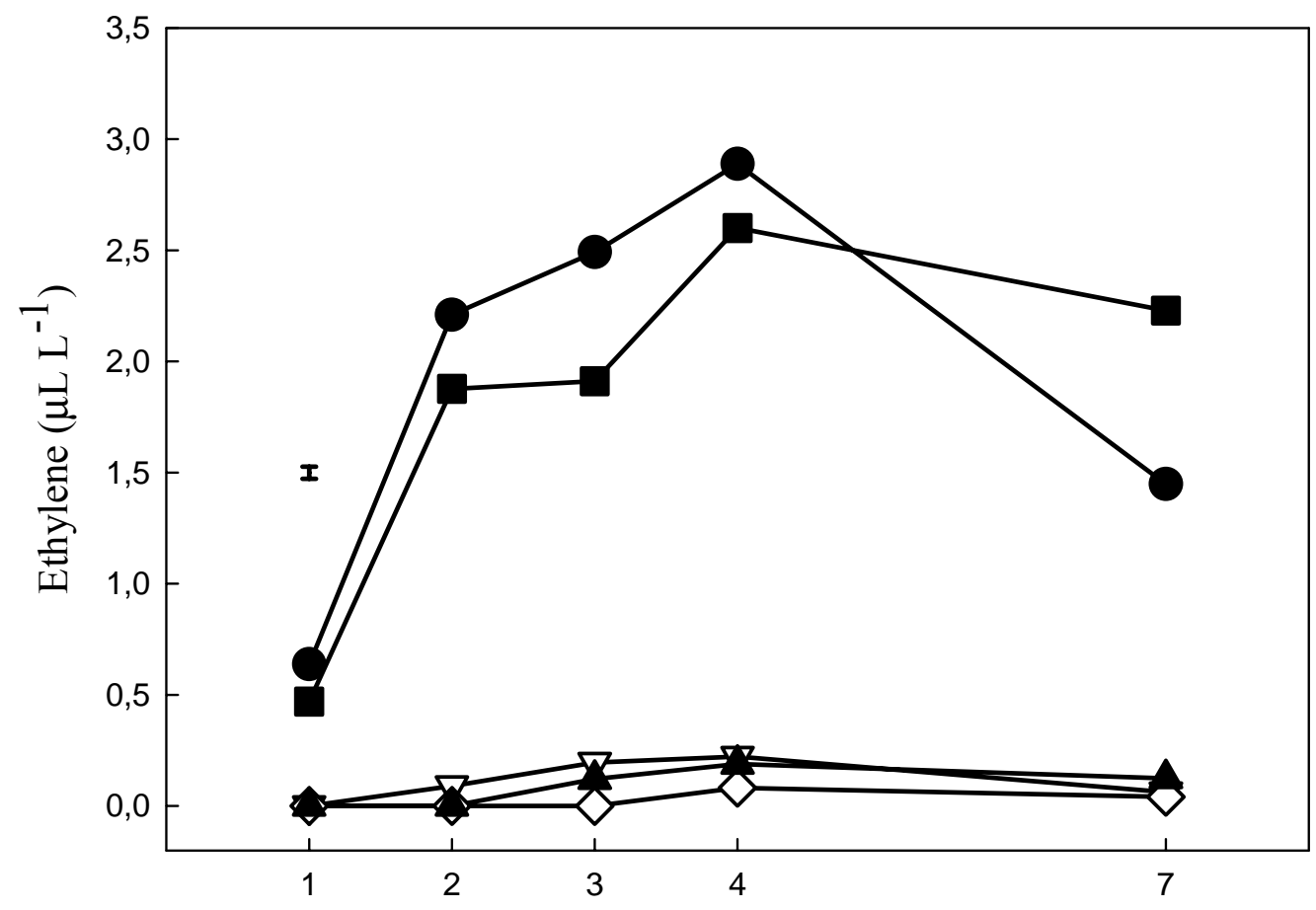

Storage days

Figure 1. Effect of treatments $\left(\mathrm{e}+{ }^{\circledR}\right.$ Ethylene Remover, $\nabla ; 1-\mathrm{MCP}, \mathbf{m} ; 1-\mathrm{MCP}+\mathrm{e}+{ }^{\circledR}$ Ethylene Remover, $\diamond$; delayed $\mathrm{e}^{\circledR}{ }^{\circledR}$ Ethylene Remover, $\boldsymbol{\Delta}$; controls, $\bullet$ ) on ethylene concentrations inside experimental chambers containing avocado cv. Hass fruit stored at $12^{\circ} \mathrm{C}$. Boxes were opened at regular intervals. Bar represents $\operatorname{LSD}(P<0.05)$.

This article is protected by copyright. All rights reserved. 


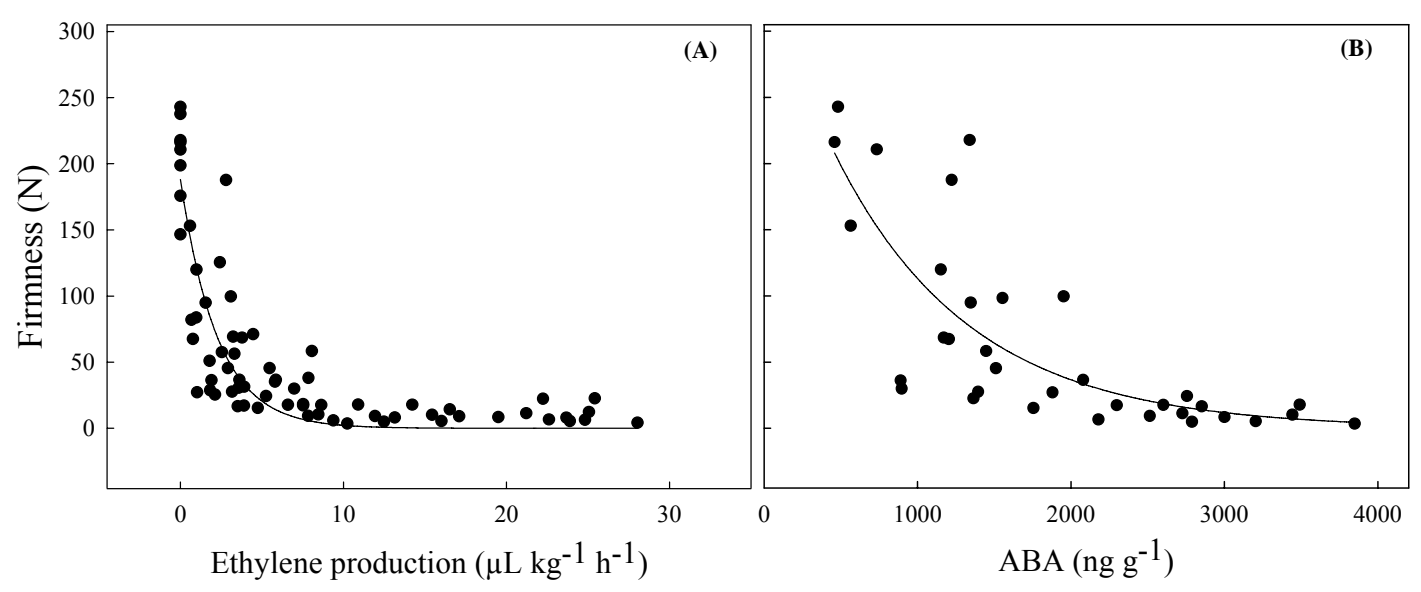

Figure 2. Change in firmness of avocado cv. Hass fruit stored at $12^{\circ} \mathrm{C}$ as a function of ethylene production (A) and endogenous ABA concentration (B). The exponential decay curve has an equation $y=a \exp (-b x)$, where $a$ reflects the estimated initial firmness (when $x=0$ ) and $b$ is the decay constant. The values of constant for the exponential decay curve $y=a \exp (-b x)$ were $a=1880.2051, b=0.4435$ and $\mathrm{r}^{2}=0.76$ (A) and $a=348.9954, b=0.0011$ and $\mathrm{r}^{2}=0.61(\mathrm{~B})$, where $a$ reflects the estimated initial firmness (when $x=0$ ), $b$ is the decay constant and $r^{2}$ is the coefficient of determination for the fitted curves.

This article is protected by copyright. All rights reserved. 
Table 1. Respiration rate $\left(\mathrm{mL} \mathrm{kg}^{-1} \mathrm{~h}^{-1}\right)$ of avocado cv. Hass fruit treated with 1-MCP, e $+{ }^{\circledR}$ Ethylene Remover (e+ ${ }^{\circledR}$ ER), delayed application of $\mathrm{e}+{ }^{\circledR}$ Ethylene Remover or combination of 1-MCP $+\mathrm{e}+{ }^{\circledR}$ Ethylene Remover and stored for 7 days at $12^{\circ} \mathrm{C}$. Respiration rate was measured at $12^{\circ} \mathrm{C}$ or $20^{\circ} \mathrm{C}$. Results represent mean values of 3 replicates $\pm \mathrm{SE}$.

\begin{tabular}{|c|c|c|c|c|c|c|c|}
\hline Temperature & Storage (days) & Control & $\mathrm{e}+{ }^{\circledR} \mathrm{ER}$ & Delayed e $+{ }^{\circledR}$ ER & 1-MCP & $1-\mathrm{MCP}+\mathrm{e}+{ }^{\circledR} \mathrm{ER}$ & Mean \\
\hline \multirow[t]{7}{*}{$12^{\circ} \mathrm{C}$} & 1 & $40.7 \pm 0.51$ & $34.9 \pm 1.88$ & $27.7 \pm 4.29$ & $29.1 \pm 2.87$ & $31.1 \pm 5.56$ & $32.7^{b}$ \\
\hline & 2 & $51.9 \pm 3.09$ & $50.0 \pm 9.34$ & $43.9 \pm 5.91$ & $38.9 \pm 0.90$ & $34.5 \pm 2.36$ & $43.8 \mathrm{a}$ \\
\hline & 3 & $53.4 \pm 0.85$ & $42.6 \pm 8.20$ & $43.9 \pm 2.63$ & $41.0 \pm 3.69$ & $41.2 \pm 2.82$ & $44.4^{\mathrm{a}}$ \\
\hline & 4 & $59.3 \pm 5.45$ & $49.0 \pm 3.47$ & $50.4 \pm 4.36$ & $48.1 \pm 5.14$ & $40.4 \pm 3.58$ & $49.4^{\mathrm{a}}$ \\
\hline & 5 & $49.8 \pm 3.59$ & $40.2 \pm 4.18$ & $49.1 \pm 12.48$ & $42.9 \pm 17.78$ & $47.9 \pm 18.12$ & $46.0^{\mathrm{a}}$ \\
\hline & 7 & $58.5 \pm 12.73$ & $46.4 \pm 8.93$ & $51.9 \pm 8.22$ & $37.3 \pm 6.74$ & $28.4 \pm 1.36$ & $44.5^{\mathrm{a}}$ \\
\hline & Mean & $52.3^{\mathrm{a}}$ & $43.9^{\mathrm{b}}$ & $44.5^{\mathrm{ab}}$ & $39.6^{\mathrm{b}}$ & $37.3^{\mathrm{b}}$ & \\
\hline \multirow[t]{7}{*}{$20^{\circ} \mathrm{C}$} & 1 & $47.8 \pm 4.04$ & $46.1 \pm 17.86$ & $34.0 \pm 1.93$ & $51.7 \pm 13.72$ & $37.3 \pm 4.61$ & $43.4^{\mathrm{a}}$ \\
\hline & 2 & $45.5 \pm 2.74$ & $43.0 \pm 3.17$ & $45.9 \pm 7.49$ & $36.9 \pm 3.35$ & $45.0 \pm 6.61$ & $43.3^{\mathrm{a}}$ \\
\hline & 3 & $61.7 \pm 2.84$ & $54.5 \pm 6.49$ & $47.7 \pm 3.83$ & $66.1 \pm 25.94$ & $50.4 \pm 7.00$ & $56.1^{\mathrm{a}}$ \\
\hline & 4 & $62.9 \pm 2.68$ & $54.1 \pm 2.05$ & $56.1 \pm 1.32$ & $38.2 \pm 3.01$ & $41.9 \pm 0.41$ & $50.7^{\mathrm{a}}$ \\
\hline & 5 & $82.4 \pm 19.56$ & $57.3 \pm 4.71$ & $52.2 \pm 2.46$ & $49.0 \pm 12.12$ & $32.0 \pm 2.51$ & $58.4^{\mathrm{a}}$ \\
\hline & 7 & $44.9 \pm 2.54$ & $49.8 \pm 3.48$ & $48.4 \pm 10.54$ & $54.8 \pm 24.05$ & $51.5 \pm 18.89$ & $49.9^{\mathrm{a}}$ \\
\hline & Mean & $57.5^{\mathrm{a}}$ & $54.0^{\mathrm{a}}$ & $47.4^{\mathrm{a}}$ & $49.5^{\mathrm{a}}$ & $43.0^{\mathrm{a}}$ & \\
\hline
\end{tabular}

${ }^{\mathrm{ab}}$ different letters indicate significant difference between means $(P<0.05)$

This article is protected by copyright. All rights reserved. 
Table 2. Ethylene production $\left(\mu \mathrm{L} \mathrm{kg}{ }^{-1} \mathrm{~h}^{-1}\right)$ of avocado cv. Hass fruit treated with 1-MCP, e+ ${ }^{\circledR}$ Ethylene Remover (e+ ${ }^{\circledR}$ ER), delayed application of $\mathrm{e}+{ }^{\circledR}$ Ethylene Remover or combination of 1-MCP $+\mathrm{e}+{ }^{\circledR}$ Ethylene Remover and stored for 7 days at $12^{\circ} \mathrm{C}$. Values are average of respiration at $12^{\circ} \mathrm{C}(n=3$ replicates $)$ and $20^{\circ} \mathrm{C}(n=3$ replicates $) \pm \mathrm{SE}$.

\begin{tabular}{ccccccc}
\hline Storage (days) & Control & $\mathrm{e}^{+{ }^{\circledR}} \mathrm{ER}$ & Delayed $\mathrm{e}+{ }^{\circledR} \mathrm{ER}$ & 1-MCP & 1-MCP $+\mathrm{e}+{ }^{\circledR}$ ER & Mean \\
\hline 1 & $3.3 \pm 1.27$ & $0.7 \pm 0.41$ & $0.8 \pm 0.32$ & $0.9 \pm 0.57$ & $1.8 \pm 0.73$ & $1.5^{\mathrm{c}}$ \\
2 & $7.5 \pm 1.01$ & $5.6 \pm 1.43$ & $5.0 \pm 1.45$ & $4.3 \pm 0.81$ & $1.5 \pm 0.85$ & $4.8^{\mathrm{c}}$ \\
3 & $17.8 \pm 1.99$ & $9.6 \pm 4.00$ & $14.2 \pm 1.91$ & $5.8 \pm 1.25$ & $5.2 \pm 0.74$ & $10.5^{\mathrm{b}}$ \\
4 & $14.0 \pm 3.09$ & $15.9 \pm 3.00$ & $16.0 \pm 3.13$ & $5.6 \pm 1.44$ & $8.3 \pm 1.93$ & $12.0^{\mathrm{b}}$ \\
5 & $18.6 \pm 2.65$ & $15.8 \pm 2.94$ & $14.2 \pm 2.23$ & $4.0 \pm 0.92$ & $8.2 \pm 3.57$ & $12.1^{\mathrm{b}}$ \\
7 & $20.0 \pm 1.47$ & $19.5 \pm 1.85$ & $18.3 \pm 2.68$ & $29.2 \pm 13.51$ & $12.8 \pm 1.32$ & $20.0^{\mathrm{a}}$ \\
Mean & $13.5^{\mathrm{a}}$ & $11.2^{\mathrm{ab}}$ & $11.4^{\mathrm{ab}}$ & $8.3^{\mathrm{bc}}$ & $6.3^{\mathrm{c}}$ &
\end{tabular}

$\overline{\mathrm{abc}}$ different letters within the same row or the same column indicate significant difference between means $(P<0.05)$.

Mean ethylene production value at baseline (upon arrival at laboratory) was $0.96 \pm 0.94 \mu \mathrm{L} \mathrm{kg}^{-1} \mathrm{~h}^{-1}$.

This article is protected by copyright. All rights reserved. 
Table 3. Firmness (Newtons, N) of avocado cv. Hass fruit treated with 1-MCP, e+ ${ }^{\circledR}$ Ethylene Remover $\left(\mathrm{e}+{ }^{\circledR}\right.$ ER), delayed application of e+ ${ }^{\circledR}$ Ethylene Remover or combination of 1-MCP $+\mathrm{e}+{ }^{\circledR}$ Ethylene Remover and stored for 7 days at $12^{\circ} \mathrm{C}$. Values in brackets are log transformed means.

\begin{tabular}{|c|c|c|c|c|c|c|}
\hline Storage (days) & Control & $\mathrm{e}+{ }^{(B)} \mathrm{ER}$ & Delayed e $+{ }^{\circledR}$ ER & 1-MCP & $1-\mathrm{MCP}+\mathrm{e}+{ }^{\mathbb{R}} \mathrm{ER}$ & Mean \\
\hline \multirow[t]{2}{*}{1} & 86.4 & 146.7 & 148.8 & 172.5 & 171.9 & $145.2^{\mathrm{A}}$ \\
\hline & $\left(4.26^{\mathrm{y}}\right)$ & $\left(4.94^{\mathrm{x}}\right)$ & $\left(4.97^{\mathrm{x}}\right)$ & $\left(5.10^{\mathrm{x}}\right)$ & $\left(5.05^{\mathrm{x}}\right)$ & $\left(4.86^{\mathrm{a}}\right)$ \\
\hline \multirow[t]{2}{*}{2} & 46.0 & 66.7 & 74.2 & 62.6 & 113.0 & $72.5^{\mathrm{B}}$ \\
\hline & $\left(3.67^{y}\right)$ & $\left(4.04^{\mathrm{xy}}\right)$ & $\left(4.10^{x y}\right)$ & $\left(4.05^{\mathrm{xy}}\right)$ & $\left(4.56^{x}\right)$ & $\left(4.09^{b}\right)$ \\
\hline \multirow[t]{2}{*}{3} & 11.4 & 43.8 & 27.8 & 35.8 & 37.6 & $31.3^{\mathrm{C}}$ \\
\hline & $\left(2.32^{y}\right)$ & $\left(3.34^{x}\right)$ & $\left(3.14^{\mathrm{x}}\right)$ & $\left(3.53^{\mathrm{x}}\right)$ & $\left(3.49^{\mathrm{x}}\right)$ & $\left(3.16^{\mathrm{c}}\right)$ \\
\hline \multirow[t]{2}{*}{4} & 18.8 & 15.9 & 13.1 & 33.3 & 38.4 & $23.9^{\mathrm{CD}}$ \\
\hline & $\left(2.79^{\mathrm{yz}}\right)$ & $\left(2.60^{z}\right)$ & $\left(2.44^{\mathrm{Z}}\right)$ & $\left(3.44^{\mathrm{x}}\right)$ & $\left(3.33^{x y}\right)$ & $\left(2.92^{c}\right)$ \\
\hline \multirow[t]{2}{*}{5} & 7.9 & 7.6 & 8.0 & 20.8 & 26.9 & $14.2^{\mathrm{D}}$ \\
\hline & $\left(1.91^{\mathrm{y}}\right)$ & $\left(1.99^{\mathrm{y}}\right)$ & $\left(2.02^{y}\right)$ & $\left(2.99^{\mathrm{x}}\right)$ & $\left(3.11^{\mathrm{x}}\right)$ & $\left(2.41^{\mathrm{d}}\right)$ \\
\hline \multirow[t]{2}{*}{7} & 6.7 & 3.7 & 3.1 & 10.9 & 17.9 & $8.5^{\mathrm{D}}$ \\
\hline & $\left(1.70^{\mathrm{yz}}\right)$ & $\left(1.28^{\mathrm{z}}\right)$ & $\left(1.13^{\mathrm{z}}\right)$ & $\left(2.28^{\mathrm{xy}}\right)$ & $\left(2.81^{\mathrm{x}}\right)$ & $\left(1.84^{\mathrm{e}}\right)$ \\
\hline \multirow[t]{2}{*}{ Mean } & $29.6^{\mathrm{C}}$ & $47.4^{\mathrm{B}}$ & $45.8^{\mathrm{B}}$ & $56.0^{\mathrm{AB}}$ & $67.6^{\mathrm{A}}$ & \\
\hline & $\left(2.77^{b}\right)$ & $\left(3.03^{b}\right)$ & $\left(2.97^{\mathrm{b}}\right)$ & $\left(3.57^{\mathrm{a}}\right)$ & $\left(3.72^{\mathrm{a}}\right)$ & \\
\hline
\end{tabular}

${ }^{\mathrm{xyz}}$ different letters within the same row (day) indicate significant difference between treatments $(P<0.05)$; LSD used for log transformed data. $^{\text {abcde }}$ different letters indicate significant difference between means of treatments or storage days $(P<0.05)$; LSD used for log

This article is protected by copyright. All rights reserved. 
transformed data. ${ }^{\mathrm{ABCD}}$ different letters indicate significant difference between means of treatments or storage days ( $\left.P<0.05\right)$; LSD used for back transformed data. Mean firmness value at baseline (upon arrival at laboratory) was $196.0 \pm 50.8 \mathrm{~N}$.

This article is protected by copyright. All rights reserved. 
Table 4. Hue angle $\left(\mathrm{H}^{\circ}\right)$ of avocado cv. Hass fruit treated with 1-MCP, e+ ${ }^{\circledR}$ Ethylene Remover $\left(\mathrm{e}+{ }^{\circledR}\right.$ ER), delayed application of $\mathrm{e}+{ }^{\circledR}$ Ethylene Remover or combination of $1-\mathrm{MCP}+\mathrm{e}+{ }^{\circledR}$ Ethylene Remover and stored for 7 days at $12^{\circ} \mathrm{C}$.

\begin{tabular}{ccccccc}
\hline Days & Control & e ${ }^{\left({ }^{\circledR}\right.}$ ER & $\begin{array}{c}\text { Delayed } \\
\mathrm{e}+{ }^{\circledR} \mathrm{ER}\end{array}$ & 1-MCP & $\begin{array}{c}\text { 1-MCP }+ \\
\mathrm{e}+{ }^{\circledR} \mathrm{ER}\end{array}$ & Mean \\
\hline 1 & 113.51 & 119.14 & 121.38 & 120.46 & 119.96 & $118.89^{\mathrm{A}}$ \\
2 & 106.27 & 109.78 & 111.58 & 113.51 & 118.23 & $111.87^{\mathrm{B}}$ \\
3 & 97.67 & 106.53 & 105.88 & 105.44 & 109.79 & $105.06^{\mathrm{C}}$ \\
4 & 94.22 & 93.35 & 94.47 & 102.38 & 97.63 & $96.41^{\mathrm{D}}$ \\
5 & 80.70 & 90.21 & 83.44 & 92.93 & 94.72 & $88.40^{\mathrm{E}}$ \\
7 & 65.61 & 58.66 & 63.43 & 68.25 & 71.54 & $65.50^{\mathrm{F}}$ \\
Mean & $93.00^{\mathrm{C}}$ & $96.28^{\mathrm{BC}}$ & $96.69^{\mathrm{BC}}$ & $100.50^{\mathrm{AB}}$ & $101.98^{\mathrm{A}}$ & \\
\hline
\end{tabular}

$\overline{\mathrm{ABCDEF}}$ different letters within the same row or same column indicate significant difference between means $(P<0.05)$. Mean $\mathrm{H}^{\circ}$ value at baseline (upon arrival at laboratory) was $118.22 \pm 2.91$.

This article is protected by copyright. All rights reserved. 
Table 5. Sugars content of avocado cv. Hass fruit stored for 7 days at $12^{\circ} \mathrm{C}$. Values are means of treatments (controls, 1-MCP, e+ ${ }^{\circledR}$ Ethylene Remover and 1-MCP $+\mathrm{e}^{+}{ }^{\circledR}$ Ethylene Remover). Values are expressed per residue mass (residue powder obtained after lipid removal) and per dry mass (DM).

\begin{tabular}{lcccccc}
\hline & \multicolumn{2}{c}{ Sucrose } & \multicolumn{2}{c}{ Mannhoheptulose } & \multicolumn{2}{c}{ Perseitol } \\
\cline { 2 - 6 } $\begin{array}{l}\text { Storage } \\
\text { (days) }\end{array}$ & $\begin{array}{l}\mathrm{mg} \mathrm{g}^{-1} \\
\text { residue }\end{array}$ & $\mathrm{mg} \mathrm{g}^{-1} \mathrm{DM}$ & $\mathrm{mg} \mathrm{g}^{-1}$ & $\mathrm{mg} \mathrm{g}^{-1} \mathrm{DM}$ & $\mathrm{mg} \mathrm{g}^{-1}$ & $\mathrm{mg} \mathrm{g}^{-1} \mathrm{DM}$ \\
residue & \multicolumn{3}{c}{ residue } \\
\hline 1 & 37.3 & 14.8 & $107.2^{\mathrm{a}}$ & $43.8^{\mathrm{a}}$ & 56.3 & 22.5 \\
3 & 41.5 & 15.6 & $89.8^{\mathrm{ab}}$ & $33.8^{\mathrm{b}}$ & 56.3 & 21.0 \\
5 & 44.3 & 16.5 & $75.9^{\mathrm{b}}$ & $28.4^{\mathrm{b}}$ & 53.6 & 16.8 \\
Mean & 41.0 & 15.62 & 91.0 & 35.3 & 55.4 & 21.09 \\
ab different letters indicate significant difference between means $(P<0.05)$. & Mean value \\
at baseline (upon arrival at laboratory) & was 15.4 $\mathrm{mg} \mathrm{g}^{-1} \mathrm{DM}$ for sucrose, 35.6 mg g ${ }^{-1}$ \\
DM for mannoheptulose and 18.7 $\mathrm{mg} \mathrm{g}^{-1} \mathrm{DM}$ for perseitol.
\end{tabular}

This article is protected by copyright. All rights reserved. 
Table 6. ABA concentration in mesocarp of avocado cv. Hass fruit treated with 1-MCP, e $+{ }^{\circledR}$ Ethylene Remover (e+ ${ }^{\circledR}$ ER) or $1-\mathrm{MCP}+\mathrm{e}+{ }^{\circledR}$ Ethylene Remover and stored at $12^{\circ} \mathrm{C}$. Values are expressed per residue mass (residue powder obtained after lipid removal), per dry mass (DM) and per fresh mass (FM).

\begin{tabular}{|c|c|c|c|c|c|c|}
\hline & Storage (day) & Control & $\mathrm{e}+{ }^{\mathbb{R}} \mathrm{ER}$ & 1-MCP & $\begin{array}{c}1-\mathrm{MCP}+\mathrm{e}^{+{ }^{\circledR}} \\
\mathrm{ER}\end{array}$ & Mean \\
\hline \multirow{3}{*}{$\mathrm{ng} \mathrm{g}^{-1}$ residue } & 1 & $1429.8^{\mathrm{ef}}$ & $1413.4^{\mathrm{ef}}$ & $586.2^{\mathrm{g}}$ & $951.9^{\mathrm{fg}}$ & $1095.3^{C}$ \\
\hline & 3 & $2564.6^{\mathrm{bc}}$ & $1321.4^{\mathrm{ef}}$ & $1794.7^{\mathrm{de}}$ & $1033.8^{\mathrm{fg}}$ & $1678.6^{\mathrm{B}}$ \\
\hline & 5 & $3446.4^{\mathrm{a}}$ & $3053.2^{\mathrm{ab}}$ & $2370.8^{\mathrm{cd}}$ & $2343.4^{\mathrm{cd}}$ & $2803.5^{\mathrm{A}}$ \\
\hline \multirow{3}{*}{$n g g^{-1} \mathrm{DM}$} & 1 & 571.2 & 554.5 & 242.9 & 385.7 & $438.6^{\mathrm{C}}$ \\
\hline & 3 & 923.8 & 466.8 & 678.5 & 407.3 & $619.1^{\mathrm{B}}$ \\
\hline & 5 & 1277.6 & 1169.2 & 902.6 & 873.0 & $1055.6^{\mathrm{A}}$ \\
\hline \multirow{3}{*}{$\operatorname{ng~g}^{-1} \mathrm{FM}$} & 1 & 166.3 & 155.9 & 70.6 & 112.8 & $126.4^{\mathrm{C}}$ \\
\hline & 3 & 272.5 & 138.1 & 203.2 & 111.6 & $181.3^{\mathrm{B}}$ \\
\hline & 5 & 371.0 & 333.8 & 275.7 & 273.5 & $313.5^{\mathrm{A}}$ \\
\hline
\end{tabular}

$\overline{a b c d e f g}$ different letters within the interaction "storage day $\mathrm{x}$ treatment" indicate significant difference $P<0.05$.

${ }^{\mathrm{ABC}}$ different letters indicate significant difference between storage days $(P<0.05)$.

Mean ABA value at baseline (upon arrival at laboratory) was $1081 \mathrm{ng} \mathrm{g}^{-1}$ residue (454 $\mathrm{ng} \mathrm{g}^{-1} \mathrm{DM} ; 124.6 \mathrm{ng} \mathrm{g}^{-1} \mathrm{FM}$ ).

This article is protected by copyright. All rights reserved. 


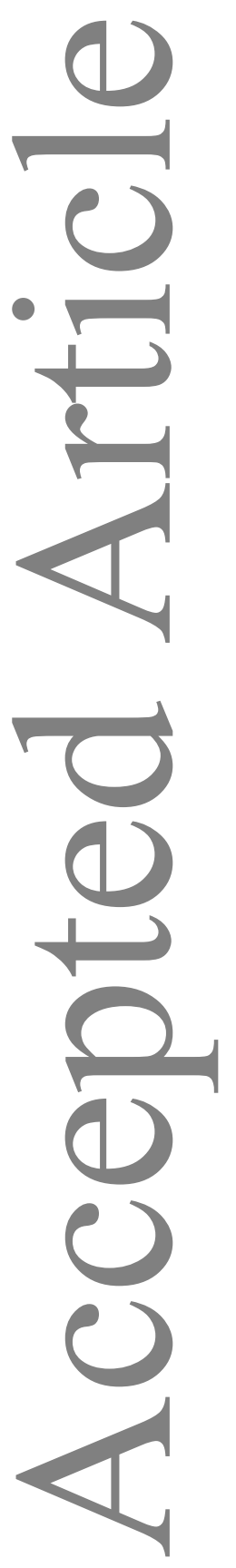

This article is protected by copyright. All rights reserved. 